\title{
Det politiske talkshow og dets publikum
}

\author{
AF HANNE BRUUN
}

\section{Resumé}

Artiklen belyser udviklingen i brug af det politiske talkshow med udgangspunkt i den radikaliserede målgruppeorientering af medieudbuddet på det internationale tv-marked. Med udgangspunkt $i$ serien Debatten (DR2) argumenteres der for, at resultatet kan betragtes som et forsøg på at skabe politisk debatjournalistik med en potentielt høj underholdningsmossig voerdi for publikum under nye medieteknologiske vilkår. Dog giver samspillet med den radikaliserede målgruppeorientering samtidig anledning til en diskussion af den politiske debatjournalistiks udfordringer og public service-institutionernes rolle som politisk forum i multiplatform-deraen.

I 1988 dukkede et program op på den nye danske public service-station TV 2 med titlen Højlunds Forsamlingshus. Fra 1988 til 1992 kunne seerne hver uge møde den karismatiske højskolemand Niels Højlund i rollen som tv-vært. Serien var dengang en ganske provokerende fornyelse af det politiske debatprogram i dansk tv og var populært blandt seerne med et gennemsnitligt seertal på $18 \%$.

Serien var del af den bølge af talkshows, der nationalt og internationalt prægede tv-journalistikken i 1990'erne (Bruun 2000). I denne artikel skal der ses nærmere på, hvordan ambitionen fra dengang om at producere nye former for politisk debatjournalistik har udviklet sig med fokus på dansk public service-tv. Som det vil fremgå, eksperimenteres der fortsat med at gøre politisk 
debatjournalistik publikumsengagerende vha. talkshowgenrens karakteristika. Men det foregår på nogle andre præmisser. Konkurrencesituationen har i samspil med de teknologiske forandringer udløst tre overordnede strategier hos medieinstitutionerne verden over. For det første kan der iagttages en nicheopdeling af tv-udbuddet (Thussu, 2007:38), og på det danske tv-marked er kanalporteføljen hos de fire væsentlige tv-udbydere, DR, TV 2, MTG/TV3 og SBS, således blevet voldsomt udvidet siden 2000 (Bruun, 2010). For det andet kan der iagttages en strategi, der på radikal vis søger at segmentere publikum, således at bestemte kanaler tilegnes specifikke målgrupper i kombination med tilbud om bestemte stofområder eller genrer. For det tredje kan der iagttages en strategi, hvor de traditionelle tv-udbydere forsøger at udvikle sig fra broadcastere til media providers af indhold på flere platforme og på tværs af disse. I Danmark er især DR og TV 2 de to væsentlige og aktive institutioner på den front, og deres forsøg på at forvandle sig til public service-media providers afspejler tilmed de nationale mediepolitiske krav, som stilles til public service-institutionerne. Målet for tv-stationerne er netop at skabe et attraktivt indhold, der kan finde sit publikum der, hvor modtagerne måtte være, eller samle et publikum på tværs af platformene (Lotz, 2009; Jones, 2009).

Den skærpede konkurrence og de nye udfordringer har tilsyneladende haft betydning for, hvordan den kreative energi blandt tv-journalister og tilrettelæggere udfolder sig, idet der i dagens forsøg på at gøre politisk debat i tv interessant i meget høj grad satses på at skabe politisk engagement hos en noget anderledes konstrueret, forudsat seer end i tv-konkurrencens barndom. Et eksempel herpå er serien Debatten på DR2, som blev lanceret i 1999 og i 2010 og 2011 undergik en ganske omfattende ansigtsløftning. I det følgende skal dette 'makeover' belyses, og interessen vil især samle sig om at få belyst, hvordan forandringen kunne tænkes at skabe en underholdningsmæssig værdi i serien, der kunne gøre serien attraktiv. En strategi, der bl.a. involverede den dramaturgiske og audiovisuelle iscenesættelse af tv-delen og brug af sociale medier i samspil med live-udsendelsen. Casen giver dog i samspil med den radikaliserede målgruppeorientering og aktuelle tendenser i den politiske debatjournalistik anledning til en diskussion af public service-institutionernes 
rolle som politiske og kulturelle fora, idet denne synes at være under ombrydning.

\section{Debatten i kontekst}

I journalistik- og medieforskningen har den skærpede konkurrence om publikum og de nye medieteknologiske vilkår givet anledning til en fornyet diskussion af ikke mindst tv-journalistikkens tilstand. Det generelle udgangspunkt synes at være, at det, der betegnes som den politiske eller den 'hårde' form for journalistik, er trængt og i krisel. To grundlæggende antagelser præger forskningsbidragene. For det første en antagelse af, at den betydningsfulde politiske tv-journalistik allerede er næsten borte. Et eksempel på dette er Turners analyser af nedlæggelser og marginalisering af aktualitetsprogrammer og politiske talkshows i australsk tv (Turner, 2005). Et andet eksempel er Thussus fremstillinger af den globale tv-journalistik, der er degenereret til 'infotainment' (Thussu, 2007), hvor underholdning i form og indhold dominerer. En anden antagelse er, at selvom der af de samme årsager er krise i den politiske tv-journalistik, så er der fortsat en central formidlingsopgave at løse, når der skal tiltrækkes og fastholdes et publikum, hvis journalistikkens ideale intention skal opfyldes. Et eksempel på denne tilgang er Anderson \& Wards bidrag (2007), hvor der bl.a. gives en definition af, hvad der skal forstås ved politisk (nyheds)journalistik og dens intention:

By this we mean journalism that covers the political/economic/ social issues that significantly affect people's lives at a global, regional, national or local level within one or several parts of the world. For now it is perhaps sufficient to say that it is journalism that can be recognised as having the primary intent to inform and encourage reflection, debate and action on political, social and economic issues. (Ibid.: 8, deres kursiveringer).

Hos Anderson \& Ward må formen ikke forveksles med indholdet eller emnet, og det centrale er at debattere:

[...] how far it is possible to reinvigorate the language and presentational formats of traditional 'hard news' journalism [...] At 
its best this is a very sophisticated and extremely demanding form of the journalist's art. (ibid.: 9).

Behovet for kreativ innovation af formidlingsformen i bred forstand sættes dermed på dagordenen. Et eksempel på en sådan analytisk dokumenteret og nuanceret bedømmelse af debatjournalistikkens tilstand og innovationsmuligheder kan findes hos Schultz (2006) i hans analyse af politiske talkshowserier i tysk tv, de såkaldte 'Polit-Talks' (Schultz, 2006:13). Analysens formål er ved hjælp af kvantitativ sprogbrugsanalyse at belyse den argumentatoriske kvalitet af seriernes diskussioner i et Habermas-inspireret offentlighedsteoretisk perspektiv. Resultatet er, at forfaldsoptikken ikke kan støttes inden for en genre, der ofte beskyldes for at være det bedste eksempel på den politiske debatjournalistiks krise. I stedet fremhæver Schultz, at denne form for debatjournalistik faktisk ikke udnytter tv-mediets dramaturgiske muligheder fuldt ud (Schultz, 2006:312-13 og 320-21). Med udgangspunkt $\mathrm{i}$, at formidlingsopgaven er under forandring og kalder på innovation af den politiske debatjournalistik, vil artiklen i det følgende fokusere på udviklingen i brugen af det politiske talkshow i dansk tv.

\section{Det kommunikative etos i forandring}

Sammenlignet med de tyske Polit-Talks er genrebrugen i dansk tv præget af en grundlæggende forgrening. For det første har såvel nichekanaler som mainstreamkanaler i de senere år prioriteret politiske talkshows, hvis tema er metapolitik, idet den politiske institution er i centrum og betragtes som et magtspil mellem aktører, der iagttages udefra, og hvor taktik og strategi blotlægges og analyseres af værten(erne) i samspil med én eller flere deltagere i programmet. Denne udvikling er uden tvivl en konsekvens af den stærkt forøgede behov for indhold til de mange nye kanaler. For det andet har niche- og mainstreamkanalerne fastholdt en mere traditionel brug af det politiske talkshow a la de tyske serier, hvor en studievært sætter aktuelle politiske temaer til debat mellem uenige deltagere. Den dramaturgiske prototype, der rammesætter denne gren, betegner Bruun som 'debatten' (2004:47-50), 
hvor konflikter mellem synspunkter, konfrontation og provokation spiller en central rolle. I begge grene er talkshowgenrens vægt på værtens personlighed dog tydeligt til stede. Denne form for politisk talkshow var i den sidste del af tv-monopolets dage i Danmark og i den tidlige periode af tv-konkurrencens tidsalder med til at forandre tv-journalistikken. Programmerne var led i et opgør med den form for politisk tv-journalistik, der prægede tvmonopolet og især dets nyhedsformidling (Hjarvard, 1999). Med inspiration fra daytime-talkshowserier såsom Donahue i USA samt en række af de såkaldte audience discussion programmes / ADP i britisk public service-tv (Livingstone \& Lunt, 1994; Bruun, 1999) tilførte dansk public service-tv den politiske debat på tv nye værdier, fx i serier som Højlunds Forsamlingshus nævnt i introduktionen.

Det karakteristiske for ADP-serierne fra dengang var, at der via den form- og indholdsmæssige iscenesættelse fandt en form for autoritetstilskrivning sted, hvor de almindelige mennesker, der deltog i programmerne, kom med indlæg i samfundspolitiske diskussioner. Det skabte dog ofte en dominerende konfliktakse mellem samfundshierarkiets top og bund i disse programmer uanset det debatterede emne, hvor disse lægfolk ofte kom til kort. Konfrontationen var sat mellem de politisk valgte og de menige vælgere, mellem magten og objektet for denne magt. Programmet, personificeret af værten, var det forum, hvor den konflikt kunne komme frem og blive italesat. Samtidig var der tale om en form for tv-journalistik, hvor det stærke følelsesmæssige engagement i den politiske debat hos de menige deltagere og værten spillede en central rolle og blev fremelsket og støttet af den dramaturgiske og audiovisuelle iscenesættelse (Bruun, 1999:297-343). ADPserierne udnyttede i meget høj grad talkshowgenrens grundlæggende karakteristika og den spænding mellem selskabelighed og usikkerhed, som denne genres attraktionsværdi er baseret på. En spænding, som desuden kan give denne form for værts- og interviewdrevet live- eller live-on- tape-tv en meget høj underholdningsmæssig værdi, bl.a. fordi det selskabelige samvær på forskellig vis 'trues' af usikkerhedselementet: I studieforløbet kan balancen mellem de to kvaliteter udfordres, og muligheden for egentlige brud på normerne for det selskabelige samvær mellem 
vært, deltagere og seere er hele tiden en mulighed, der kan orkestreres meget forskelligt.

Balancen mellem selskabelighed og usikkerhedselementet opnås dramaturgisk, og Debatten er, som også Højlunds Forsamlingshus var, baseret på prototypen 'debatten'. Midlerne til at få seerne engageret i den politiske debat via den dominerende konfliktakse mellem samfundshierarkiets top og bund og iscenesættelse af det følelsesmæssige engagement har dog på væsentlige punkter ændret sig. I Debatten er den dominerende konfliktakse fra f.eks. Højlunds Forsamlingshus væk og erstattet af en ligemandsideologi, hvor konfrontationerne udelukkende foregår mellem repræsentanter fra toppen af samfundshierarkiet. I den ansigtsløftning, som serien fik i 2010, blev denne konfrontative ligemandsideologi udvidet til også at omfatte seriens forskellige platforme, idet ikke blot et dr.dk-site, men også en Facebook-profil, blev tilføjet tv-delen. Arbejdsfordelingen mellem de tre dimensioner er, at det ugentlige højdepunkt er livebegivenheden på tv, der i løbet af ugen støttes op til, under og efter af Facebook-profilen. Desuden pitches forskellige andre emner til debat af redaktionen/værten Clement Kjersgaard, og emner til debat efterlyses ligeledes blandt Facebook-vennerne. Dr.dk-sitet fungerer som et service-site for afstemninger, tilmelding som studiepublikum og henvisning til debatmuligheden på Facebook-profilen samt indeholder et meget benyttet programarkiv, en præsentation af programmet, af redaktionen bag og af studieværten. Fra 2011 introduceres i forbindelse med liveudsendelsen to særligt inviterede deltagere på Facebook-profilen, der skal bidrage til debatten under udsendelsens afvikling på tv. De inviterede er typisk kendte dagbladsjournalister med egne blogs og politiske kommentatorer og debattører, ligeledes med egne blogs. Deltagerne/vennerne på Facebook-profilen kan under udsendelsen debattere med de inviterede venner. Debatten er på den måde det, som Lotz har beskrevet som "phenomenomenal television" (2007:35-41), hvor et mediefænomen løsrives sig fra flow-tv's karakteristika og benytter sig af andre distributionsplatforme for at opnå kontakt til publikum og synlighed. Et tv-programs betydning i den kulturelle eller politiske offentlighed opnås dermed potentielt på andre måder end alene ved tv-udsendelsens (høje) seertal. I Debatten udvikles programmet 
til at blive et flermedialt koncept (Bruun, 2007), og det er med sine godt 32.000 'venner', et gennemsnit på 300 kommentarer pr. udsendelse og et seertal på 122.000 et ret enestående eksempel i dansk tv på en succesfuld inddragelse af sociale netværksmedier.

Men hvordan kan det at ville inddrage seerne så egentlig blive et middel til at producere attraktiv, politisk debatjournalistik? I den kognitionspsykologiske underholdningsteori om medietilbuds evne til at tiltrække modtagerne formuleret afVorderer m.fl. (2006) fremhæves tre grundlæggende, oplevelsesmæssige kvaliteter, som skal være til stede, for at et medietilbud bliver opfattet som fundamentalt underholdende uanset emne og/eller genre. For det første skal det stimulere en oplevelse af autonomi, der giver individet en oplevelse af at gøre noget for én selv og af lyst frem for af pligt. Autonomioplevelsen indebærer, at individet kan få en stærk oplevelse af uafhængighed og kontrol (ibid. 7-8). For det andet skal medietilbuddet for at være underholdende stimulere en oplevelse af kompetence hos individet på en sådan måde, at medietilbuddet repræsenterer en balance mellem bemestring og udfordring, så kedsomhed undgås. Endelig skal medietilbuddet for at have underholdende kvalitet kunne give individet en oplevelse af samhørighed enten parasocialt eller socialt. Det underholdende formuleres således som noget, der befinder sig på et både helt grundlæggende og abstrakt niveau. Det gør på én gang teorien robust og ganske upræcis i forhold til konkrete mediemæssige fænomener.2 Men en kombination af denne teoretiske tilgang, talkshowgenren og debatdramaturgien vil kunne bidrage til at belyse de centrale kvaliteter, der tilføres Debatten fra 2010. Påstanden, der skal argumenteres for i den følgende analyse med fokus på tv-delen, vil derfor være, at det underholdende i form af kompetenceoplevelser prioriteres, fordi serien fastholder en leg med magt- og statusmæssig ligeværdighed i konfliktorienteringen således, at den dramaturgiske spænding mellem selskabelighed og usikkerhedselementet fastholdes. At levere basis for kompetenceoplevelser synes tilmed at være vejen til potentielle samhørighedsoplevelser. Analysen fokuserer således på, hvordan tv-delen af programmet sætter rammerne for et særligt kommunikativt etos. 


\section{At ophæve magtdistinktioner}

Tv-delen skaber et programunivers, hvor magtdistinktioner søges ophævet, og hvor den forudsatte seer har ret til at deltage i debatten på lige fod med de medvirkende. Det indtryk søges opnået ved den positionering af seerne, serien tilbyder, via scenografi og forløbsstrukturering af tv-delen af serien og casting af debattører. Følgende klip fra YouTube kan give et indtryk af, hvordan studiet er indrettet:

http://www.youtube.com/watch?v=LkozCNud3BQ

De otte talerstole i den lille vinkel på det hvide gulv har den store vinkel af siddepladser til studiepublikum og debattører bag sig, hvor alle ved talerstolene i perioder af programforløbet er placeret. Herfra hentes de ind i den lille vinkel af værten og placeres som modstandere i hvert sit 'ben', så de ser på hinanden og værten. Værten bliver i sit geografiske område foran de to vinkler udsendelsen igennem, men bevæger sig meget rundt i dette område, og herfra sker også henvendelserne til seerne under udsendelsen. Seernes perspektiv i forhold til rummet er udsendelsen igennem således, at alt ses fra studieværtens geografiske område og ikke fra publikums. Den scenografiske grundmodels umiddelbare værdimæssige udsagn synes at være, at selvom enkelte personer fremstår som centrale i udsendelsens forløb og som modstandere i en konflikt, så er de alle en del af det fælles udgangspunkt. De udgør en gruppe af ligeværdige aktører, der på forskellige tidspunkter fremkaldes og bringes i konfrontation af studieværten, så deres synspunkter på temaet for udsendelsen kan fremføres over for værten og seerne og til seernes bedømmelse. Men konfliktaksen og dermed adskillelsen mellem debattørerne og seernes repræsentanter i studiet, publikum, er netop kun midlertidig, og under udsendelsen filmes debattørerne hele tiden med publikum som baggrund. Kort sagt, debattørerne er ikke 'mere end' eller 'bedre end', men derimod medlemmer af publikum, og seerne kunne selv være/er selv debattører.

Den scenografiske konstruktion af denne seerposition støttes af struktureringen af udsendelsesforløbet, som deles op imellem tre og fem akter af mellem 5 og 15 minutters varighed og med 
hvert sit tema, der fastholdes vha. kravletekster i bunden af tvskærmen. I hver akt konfronteres forskellige kategorier af magtfulde aktører fra samfundshierarkiets top inden for partipolitik, forskning, medier og diverse civile organisationer, der alle må argumentere for deres synspunkter i et stramt orkestreret forløb foran seerne. De castede debattører er netop ikke lægfolk, der taler på baggrund af egne erfaringer, og det er heller ikke lægfolk i konfrontation med de magtfulde. Men efter hver akt sendes disse højstatus-personer retur til pladsen blandt publikum, og ingen er i den forstand vigtigere end andre. Seerpositioneringen som ligeværdig deltager understøttes desuden ved hjælp af Facebook-profilen, hvor debattørernes 'performance' løbende kommenteres, og hvor det er muligt for de empiriske seere at komme med egne og se andres bidrag til debatten.

Denne prioritering af at skabe en oplevelse af ligeværdighed hos seerne kunne betyde, at serien i samspil med - og i nogen grad uanset - de debatterede emner giver en oplevelse af kompetence hos en empirisk seer, hvilket kunne bidrage til, at en elementær underholdningsmæssig værdi er at finde i serien.

\section{Status på spil}

Den konfrontative ligemandsideologi, der præger serien, og dens potentielle underholdningsmæssige værdi centreret om kompetenceoplevelser produceres dog ikke alene ved at positionere den forudsatte seer på niveau med debattørerne. Det sker også ved systematiske forsøg på at ryste disse muligvis medietrænede debattører, så de kan opleves som mennesker i øjenhøjde med seerne. Programuniverset fremstår på flere måder som ganske risikofyldt for debattørerne og som en test på deres evner til at klare sig i programmets drama og ikke alene på deres synspunkters overbevisningskraft. Det skyldes to dramaturgiske greb, som udnytter talkshowets usikkerhedselement til at holde intensiteten og dramatikken oppe, hvilket skal udfoldes i det følgende.

For det første skaber castingen og orkestreringen af debattørerne i de enkelte akter en grad af uforudsigelighed i konfrontationerne. Der bliver nemlig lagt op til maksimalt konfliktpotentiale i 
alle akter, hvilket skaber små minidramaer mellem debattørerne i forløbet. Et eksempel på dette kan ses i udsendelsen d. 9-122010 om den danske folkeskole med titlen "Er folkeskolen dumpet?". I udsendelsens anden akt konfronteres Undervisningsministeren, der forsvarer den daværende regerings nye forslag til en skolepolitik, med elevforeningens formand, der mener, at det grundlæggende problem er de mange gensidigt uforenelige krav til skolen i forslaget, som går ud over uddannelsens kvalitet. Formanden, som er ca. 16 år gammel, fastholder sin sag over for ministeren, der forsøger at sætte ham på plads i rollen som elev ved at gentage hans fornavn med det formål at kalde ham til orden og få ham til at holde mund og høre efter. Det ulige aldersforhold i kombination med elevformandens standhaftighed og nervefasthed i kampen med den meget talende og lettere nedladende minister skaber et lille 'David mod Goliat'-drama i denne akt. 'Davids' evne til at modstå overmagten og få overtaget udløser gentagne gange latter hos publikum i studiet, som det måske kan fornemmes i klippet på ca. 9 minutter fra YouTube:

http://www.youtube.com/watch?v=3TJw28vOj5k\&feature=ch annel\&list $=\mathrm{UL}$

Debattørernes status er således på spil i hver akt, og programmet placerer med denne strategi den forudsatte seer i en position, hvorfra det kan bedømmes, hvordan debattørernes status fremtræder og ikke mindst udvikler sig i konfrontationen med en modstanders synspunkter og ageren i situationen. Positionen som dommer i forhold til de magtfulde højstatus-debattører underbygges endvidere af, at de små dramaer i hver akt giver en sekvensstruktur i talestrømmen i programmet som helhed. Denne orkestrering gør det muligt at fastholde, overskue og tage stilling til relativt tydelige uenigheder mellem debattørerne minidrama for minidrama. På den måde gør serien diskussionen både tilgængelig og overskuelig for den forudsatte seer, og en oplevelse af kompetence bliver en mulig attraktion, hvilket igen kunne være med til at skabe en underholdningsmæssig værdi for den empiriske seer.

At status er på spil i Debatten skyldes for det andet iscenesættelsen af studieværten, som på en række måder skaber et stressfyldt univers, hvor debattørernes høje status systematisk angribes i et 
forsøg på at degradere den, hvilket kunne støtte kompetenceoplevelse som underholdningsmæssig værdi. Værtens funktion er først og fremmest at holde konfrontationerne og fremdriften i debatten ved lige med sit eget personlige engagement i udsendelsens emne. Det sker ved, at der især lægges vægt på værtens rolle som programleder i serien frem for hans rolle som ordstyrer. Det betyder, at debattørerne let fremstår som talende marionetdukker i værtens univers af fortløbende konfrontationer. Programlederrollens dominans er især en konsekvens af programforløbets akt-struktur, hvor de forskellige debattører deltager som hinandens modstandere, og den er en konsekvens af den måde, der tales til debattørerne på i sceneskiftet mellem de forskellige akter. Et eksempel fra folkeskole-programmet er skiftet mellem første og anden akt, hvor beskeden til debattørerne fra værtens side er "Ok, foreløbig tak. Troels, du bliver stående. I andre må gerne sætte jer ned." Derefter kaldes Undervisningsministeren frem i arenaen med følgende velkomst:

Og her kommer gående ind til os på gulvet Undervisningsminister Tina Nedergaard. Godaften og velkommen, og det er jo altså $i$ denne uge, at regeringen har fremlagt sin skolepolitik efter 9 år. $\mathrm{Nu}$ skal der ske noget, Tina. Hvorfor så sent? Hvad har I lavet?? (2. akt, 00:14:25).

Vægten på programlederrollen i Debatten betyder, at alle udsættes for denne form for håndfast og drillesyg dukkeføring, og på den måde får de ens vilkår, som de skal finde sig i.

Et andet gennemgående middel til denne degradering af debattørernes status er værtens spørgestil, der er konflikttilspidsende. Et eksempel er allerede givet i velkomstspørgsmålet til Undervisningsministeren, som straks må i gang med at forsvare sig mod anklagen mod hende og regeringen for både dovenskab og år med manglende politisk interesse for folkeskolens problemer. Ledende og voldsomt værdiladede spørgsmål af denne type er Kjersgaards kendetegn, og de stilles især, når der blandt debattørerne er tendens til for megen høflig anerkendelse af andres synspunkter og optræk til enighed. Et eksempel er en enighed mellem debattørerne i første akt af folkeskole-programmet om, at lærerne har været udsat for et forældreskabt tab af respekt 
og autoritet i folkeskolen. Men skyldsspørgsmålet reformuleres hurtigt af værten og stiles til lærerforeningens formand blandt de fire debattører: "Har I ikke selv bidraget til dette autoritetstab?", hvilket genstarter uenigheden blandt de fire. Desuden tilspidses udsagn ved at reformulere en debattørs udsagn i forhold til en anden debattør, så det fremstår som et angreb.

Det tredje greb, der er med til at gøre universet risikofyldt for debattørernes status, er, at ordstyrerrollen forvaltes på en speciel måde i Debatten. Når ordet via et spørgsmål af den beskrevne type gives til en debattør, er reglen i serien, at debattøren skal se på den, vedkommende er uenig med. Angrebet sendes således direkte i ansigtet på modstanderen frem for at gå via værten. Dette betyder, at der let opstår situationer, hvor disse ellers ofte voldsomt mediehærdede debattører overskrider reglen om at lade den anden tale ud og begynder at tale i munden på hinanden og ignorerer værtens forsøg på at styre. Følelserne tager overhånd, og finker ryger af panden. Endelig søges degraderingseffekten også opnået ved, at Kjersgaard gør grin med synspunkter fra disse højstatus-aktører. I fjerde akt af folkeskole-programmet har han eksempelvis følgende reaktion henvendt til kamera på Socialdemokraternes plan om at indføre heldagsskole for at løse de mange opgaver, folkeskolen pålægges: " [...] man slipper aldrig ud af skolen. Vi er nogen, der er glade for, at vi slap ud i tide, fordi man er der hele tiden!" (0:44:02).

Det risikofyldte univers, der skabes ved hjælp af disse dramaturgiske tiltag, betyder, at der fastholdes en spænding i serien mellem talkshowets selskabelighed, der fordrer en vægt på den friktionsløse og respektfulde behandling af menneskelig ære og værdighed og på kommunikative høflighedsregler, og usikkerhedselementets vægt på at bryde med netop disse kvaliteter. Spændingen placerer den forudsatte seer på niveau med højstatus-aktørerne i programmet, netop fordi deres status som professionelle debattører hele tiden udsættes for fare og ind imellem faktisk eroderes. Samtidig betyder castingen af debattører, at der hele tiden tilskrives eller fraskrives status til aktører med meget forskellige tilgange til emnet for debatten. Begge dele kunne skabe basis for oplevelser af kompetence hos den empiriske seer, der evt. på tværs af holdninger og synspunkter igen skaber basis for samhørighedsoplevelser hos den empiriske seer. Det risiko- 
fyldte univers producerer nemlig et element af forsonlig menneskelighed i serien.

\section{En privilegeret position}

Ud over arbejdet med dramaturgien og dens konsekvenser for det kommunikative etos i programuniverset ændrer Debatten sin audiovisuelle stil fra 2010. Den er med til at placere den forudsatte seer i en særlig position i forhold til deltagerne i programmet og i forhold til værten. Billedbrugen er præget af, at der er en meget høj klippefrekvens blandt de tre kameraer i akterne, hvilket giver oplevelsen af et højt tempo. Billedvalget er desuden helt domineret af halvnære indstillinger af ansigter, og alle billeder indeholder et hav af ansigter, der kan nærstuderes under den enkelte indstilling qua den scenografiske indretning. Pga. reglen om, at debattørerne skal henvende sig til hinanden, er de mange halvnære indstillinger af ansigter desuden præget af, at der prioriteres taler- og lytterbilleder i det enkelte billede, således at begge parter kan ses samtidig. Et enkelt eksempel på denne typiske indstilling er fra tredje akt af folkeskole-programmet, hvor en forsker og lærerforeningens formand konfronteres. Dette sker knap 9 minutter inde i klippet fra YouTube:

http://www.youtube.com/watch?v=kPGRTssH94\&feature=realated

Desuden klippes masser af lytte- og reaktionsbilleder fra studiepublikum ind i akterne, så der løbende kan iagttages reaktioner, mens debatten udfolder sig på lydsiden. Den audiovisuelle stil lægger på mange måder op til en fortælling om det psykologiske drama, der udspiller sig, og med den forudsatte seer i en hypermobil mervidensposition. Den forudsatte seer gives derved en mulighed for via iagttagelser hele tiden at se mere og få mere at vide om relationen mellem deltagerne end alle andre inklusive værten. Denne position, som den audiovisuelle stil producerer, inddrager samtidig den forudsatte seer i det menneskelige samvær i studiet. Igen kunne den audiovisuelle fortællestil i Debatten tænkes at danne basis for oplevelser af såvel kompetence hos den 
empiriske seer som oplevelser af samhørighed med meningsfæller og modstandere. Denne underholdningsmæssige værdi støttes tilmed af muligheden for Facebook-dialog med højstatuspersoner i rollen som kommentatorer og programmets venner, mens dramaet udspiller sig i live-tv-delen af konceptet.

\section{Den politiske debatjournalistik i multiplatformkonkurrencens tidsalder}

Debattens 'makeover' kan betragtes som et tegn på en udvikling i kommunikativ etos i dansk public service-tv's journalistik, hvor konfrontativ ligemandsideologi har afløst en værdiorientering med konfrontation mellem aktørerne 'folket' og 'magthaverne'. Den forudsatte seer er alt andet end en offeraktant, der skal have hjælp via tv's mellemkomst inden for rammerne af dette kommunikative etos. I stedet peger de dramaturgiske og audiovisuelle karakteristika i retning af en forudsat seer, som positioneres på niveau med deltagerne i debatten og som et medlem af den debatterende politiske elite, serien dyrker som deltagere i live-tvdelen og som igangsættere for Facebook-profilens interaktivitet i forbindelse med live-udsendelsen. At denne tv-journalistiske ansigtsløftning med vægt på at skabe kompetenceoplevelser og ad den vej samhørighedsoplevelser styrkede den underholdningsmæssige værdi af serien i forhold til perioden fra 2002-09, er der næppe tvivl om.

På mange måder er der således tale om, at Debatten kan betragtes som en tv-journalistisk succeshistorie på det konkrete programniveau, der peger på, hvor godt tv-mediet i samspil med sociale netværksmedier kan udnyttes inden for rammerne af et debattalkshow. Men der kan også dryppes malurt i bægeret. Til det formål skal spørgsmålet om konsekvenserne af de intensiverede konkurrenceforhold på tv-markedet og de medieteknologiske forandringer for den politiske debatjournalistik, som forskningslitteraturen kredser om, afslutningsvis adresseres. Jeg vil påpege, at behovet for kreativ innovation af den politiske debatjournalistik, som fremhæves af for eksempel Anderson \& Ward (2007) samt Schultz (2006), med fordel kan inddrage et mere forpligtende publikumsperspektiv i diskussionen. Trods den krea- 
tive udvikling af det politiske talkshow, som Debatten er et tegn på er mulig, er det i multiplatformkonkurrencens tidsalder værd at spørge, om der i kampen om de attraktive seersegmenter på paradoksal vis er en ny form for afsenderorientering på vej? Satsningen på at gøre det politiske debatprogram mere attraktivt er netop sket på DR2, hvor en målgruppe af højtuddannede, velstillede og måske i forvejen politisk interesserede serviceres på en kanal med en markedsandel på 4-5\%. Sat på spidsen er den intenderede målgruppe dermed på mange måder nærmest sammensmeltet med producenterne selv, som derfor kan lave former for tv-journalistik, de godt selv kan lide. Set i et tv-historisk lys er en kort periode i dansk public service-tv måske slut, hvor det var konkurrencemæssigt opportunt for public service-institutionerne at være bredt og mainstreamorienteret i eksperimenterne med den politiske debatjournalistik. Siden er dette blevet langt mindre attraktivt set i lyset af de målgruppemæssige udfordringer, som public service-institutionerne står i på et radikalt segmenteret tv-marked.

Den udvikling kan have konsekvenser for tv-mediets rolle, som Lotz har påpeget (2007). Hun sætter spørgsmålstegn ved Newcomb og Hirsh' banebrydende argumentation for tv-mediets rolle i samfundet som et fælles kulturelt og politisk forum fremover i en tid med radikal segmentering af publikum og multiplatformkonkurrence. Lotz' analyse tager udgangspunkt i det amerikanske postnetværksprægede tv-system og aktuelle bevægelser i seerens brugsmønstre. Trods store forskelle mellem det amerikanske og det danske tv-system, som fortsat er domineret af public service, kan visse tendenser genfindes. Seerandelene til dansk public service-tv er nedadgående sammenlagt, og især for de mainstreamorienterede hovedkanaler. Spredningen af publikum er desuden så udbredt, at det bliver stadig vanskeligere at samle seerskarer over en million (Degn, 2010; Medieudviklingen 2010, 2011). Risikoen på et meget lille tv-marked som det danske i en situation præget af radikal målgruppeorientering er, at bestemte genrer og former for indhold kun produceres til specifikke målgrupper på særlige kanaler. I forhold til den kreative udvikling af den politiske debatjournalistik kan denne praksis spærre for den kreative energi og dermed for fornyelse af formidlingsopgaven i forhold til andre målgrupper end dem, der i forve- 
jen måske er politisk interesserede og måske allerede en del af en politisk elite. Op gennem 1990'ernes tv-konkurrence i Danmark var formidlingsopgaven for tv-journalistikkens producenter at tillære sig en målgruppefølsomhed i journalistikkens indhold og form. Dette var baseret på en form for 'shotgun marriage' mellem journalistikkens ideale modtager, borgeren, og livsstilsteoriens empiriske resultater, der informerede producenterne om smagskulturer af meget forskellig art. Spørgsmålet er, hvordan de formidlingsmæssige indsigter og eventuelle færdigheder fra det fornuftsægteskab bliver bragt i anvendelse fremover i forsøget på at fastholde bestemte dele af publikum, som er særligt attraktive enten politisk og/eller kommercielt i moderne multiplatformtv-journalistik? For debatjournalistikken generelt er tendensen i dansk PS-tv i øjeblikket en målgruppeorientering, hvor mainstreampublikummet ikke længere tilbydes faste, politiske debattalkshows, men derimod problemorienterede 'social change'serier med et ad hoc-debatprogram som afslutning på serien (fx Restaurant bag Tremmer DR1 2012; Gør Danmark Dansk DR1 2012) samt korte debatindslag med seerafstemninger i magasinprogrammer. Om den form for servicering af det radikalt segmenterede publikum er en robust revitalisering af intentionerne i den politiske debatjournalistik, kan naturligvis diskuteres.

\section{REFERENCER}

Anderson, P.J. \& Ward, G. (eds.) (2007): The Future of Journalism in the Advanced Democracies. Aldershot, Ashgate.

Bruun, H. (1999): Talkshowet - portrcet af en tv-genre. Borgen, København.

Bruun (2000): "Eleva2ren - TV 2 og talkshowet". I: Bruun, H., Frandsen, K. \& Søndergaard, H. (red.) TV 2 på Skcermen. Samfundslitteratur, Frederiksberg.

Bruun (2004): Daytime talkshows i Danmark. Modtryk, Aarhus.

Bruun, H. \& Frandsen, K. (2010): Hvad er tv-underholdning? I: Bruun, H. \& Frandsen, K. (red.) Underholdende tv. Aarhus Universitetsforlag, Aarhus.

Bruun, H. (2010): "På vej mod multiplatformkonkurrence". I: Agger, G.

\&Waade, A.M. (red.) Den skandinaviske krimi. Nordicom, Gøteborg.

Degn, H. (2010): "Appendiks". I: Bruun, H. \& Frandsen, K. (red.) Under- 
holdende tv. Aarhus Universitetsforlag, Aarhus.

From, U. \& Nørgaard Kristensen, N. (2011): ”Lifestyle Journalism. Blurring boundaries". Journalism Practice, vol. 6, nr. 1.

Jones, J. (2009): "I Want My Talk TV: Network Talk Shows in a Digital Universe". I: Lotz, A. (red.) Beyond Prime Time. Television Programming in the Post-Network Era. Routledge, New York.

Livingstone, S. \& Lunt, P. (1994): Talk On Television-Audience Participation and The Public Debate. Routledge, London.

Medieudviklingen 2011, DR's Medieforskning.

Medieudviklingen 2010, DR's Medieforskning.

Lotz, A. (2007): The Television Will Be Revolutionized. New York University Press, New York.

Lotz, A. (2009) (red.): Beyond Prime Time. Television Programming in the Post-Network Era. Routledge, New York.

Hjarvard, S. (1999): Tv-nyheder $i$ konkurrence. Samfundslitteratur, København.

Schultz, T. (2006): GeSchwätz oder Diskurs? Die Rationalität politischer Talkshows im Fernsehen. Herbert von Halem Verlag, Köln.

Thussu, D.K. (2007): News as Entertainment. The Rise of Global Infotainment. Sage, London.

Turner, G. (2005): Ending the Affair. The decline of television current affairs in Australia. UNSW Press, Sydney.

Vorderer, P., Steen, F.F. \& Chan, E. (2006): "Motivation”. I: Bryant, J. \& Vorderer, P. (red.) Psychology of Entertainment. Lawrence Erlbaum Associates Publishers, London.

\section{NOTER}

1 Det er ikke artiklens formål at diskutere definitionen af 'hard' journalistik, som den fremføres i forskningen, ej heller selve den udbredte grænsedragning mellem 'hard' og 'soft' journalistik. For en nuanceret diskussion af udfordringerne til begge disse kategoriseringer af journalistik, se From \& Nørgaard Kristensen (2011).

2 En mere udfoldet kritik af denne evolutionsbiologiske, kognitionspsykologiske underholdningsteori og dens svage æstetiske, genre- og mediemæssige orientering kan læses i H. Bruun \& K. Frandsen (2010). 